\title{
Professional Knowledge and Professionalism Teaching in Nursing Education
}

\author{
Carla Alexandra Fernandes Nascimento \\ Nursing College of Lisbon (ESEL); Nursing Research and Development Unit (UI \& DE), Lisbon, Portugal
}

\begin{abstract}
Nursing education suffered many huge changes in last years. These modifications justify the need of a profound reflection of nursing teachers' education, not only about their scientific and technological knowledge about nursing, but also about their educational knowledge. Although relevance of the pedagogic in nursing teachers' education has been recognized and efforts have been made to integrate it in the professional profile, we know little about what teachers in the field think about what constitutes their professionalism as well as the place that should be occupied by pedagogical training in their professional education. The aim of the study was to answer three questions: 1 . What perspectives of teaching do nursing teachers share? 2. What professional knowledge do nursing teachers recognize in the teaching practice? and 3. What training do nursing teachers indicate as a reference in terms of professionalism teaching? The study follows the interpretive paradigm of research and uses a predominantly quantitative methodology, based on the questionnaire given to nursing teachers of 10 nursing schools (450 questionnaires delivered, with 227 valid responses). For the construction of the questionnaire, semi-structured exploratory interviews were conducted. The results permitted to define an array of conceptual knowledge and professionalism teaching in nursing that consists of three axes: 1. The mission of nursing teaching is "to make learn"; 2. The knowledge of professional teachers of education is embedded in nursing education; and 3. The pedagogical training is in the processes of (trans)formation and teachers' professional development in nursing.
\end{abstract}

Keywords: nursing teacher, professional teaching knowledge, professionalism teaching

\section{Introduction}

In Portugal, the integration of nursing education in higher education happened just a little over two decades ago. Since then, many changes have been introduced in the field of vocational training, especially in terms of the adjustment of professional training, the increased interest and demand for postgraduate training, the growing number of students, the diversity of educational institutions, the institution's integration in universities, and the development of scientific knowledge in the subject area.

The speed at which these changes have been produced does not truly favor moments of formal analysis and reflection on variables that would be important to consider. One of these variables is a teacher's professional preparation in nursing, not only as a holder of scientific and technical knowledge and experiential knowledge, but also as a teaching professional. Access to nursing teaching activity seems to happen according to a handmade and traditional model of the teacher and his/her professional knowledge. Mostly, nursing

Carla Alexandra Fernandes Nascimento, Ph.D., professor, Department of Medical-Surgical, Nursing College of Lisbon (ESEL); reseacher, Nursing Research and Development Unit (UI \& DE). 
teachers are nurses coming from the exercise of clinical practice and entering the teaching activity through the enhancement of the scientific knowledge in nursing, in defense of the experiential knowledge (Schön, 1983; 1987) and the practical knowledge. Their professional skills are closely related with skills in the professional field of their initial training. The integration in the teaching activity invokes new skills - teaching skills - and with them, a duality and hybridity in the identity process. The transition from one occupation to another seems to happen without a real understanding that there lies an important epistemological transformation-from the holder of knowledge and practice in nursing to the holder of knowledge and practice in the area of teaching in nursing.

Once located in higher education, nursing education has also undergone changes resulting from the proposals of the European Higher Education Area, commonly known as the Bologna Process, an ambitious and complex project that requires in-depth analysis and thoughtfully reviewing of not only the contents of curricula, but also new methodologies in the teaching and learning processes, which implies a reconceptualization of the roles of teachers and students. As has often been written, the Bologna Process suggests a new teaching profile redefining the roles of key stakeholders: teachers, asking them to focus their mission on students' learning, to be concerned with the transfer of learning to the world of work, therefore, with professional skills and labor insertion; and students, asking them for greater autonomy, responsibility, and commitment to their learning processes.

This speech has a special resonance in the teaching and learning processes and exerts a strong pressure on teachers, giving them a new role in the knowledge society - an orchestrator of activities that enables a wise construction of knowledge (Shavelson, 1992). With the responsibility to make someone learn something (Roldão, 2007), the appeal made to teachers is based on promoting significant learning by developing reflective thinking in students, considering their interests and needs in a framework consisting of a variety of audiences. Granted that much of the implementation of these principles rests on teachers, we must ask what specialized training for teaching was envisaged in recent years to the teachers of higher education, consistent with the development needs of the educational system.

As in any other profession, "Teachers must have the knowledge and skills required in order to properly perform their duties" (Zabalza, 2004, p. 8), so teacher training in higher education must consist of knowledge from scientific training both in the subject area of teaching and in the area of education, the latter is neither as a place of acquisition of knowledge to be applied in teaching practice nor as an indoctrination to empower teachers to act in prescribed ways (Fenstermacher, 1986), but as an essential resource to a new understanding of teaching in higher education and as an essential element to the culture of professional teachers of education (Zabalza, 2009). We refer to knowledge about how students learn, knowledge of curriculum, knowledge of educational policy, and knowledge about how education resources will be conducted in order to better fit the existing conditions, as Shulman (1986) pointed out in the late 1980s, and several authors supported him (Cunha, 2005; 2007; Estrela, 2001; 2005; Montero, 2005; Perrenoud, 2000; 2001; Roldão, 2005; Zabalza, 2003; 2007).

In summary, the requirements towards a new pedagogical culture reinforce the need for pedagogical training of teachers. Its invisibility reflects the undervaluation, minority, concealment, or muting of teachers' pedagogical work (Vieira, 2011). Pedagogical training becomes more urgent as we know that it is not even considered as a criterion of effective appreciation in teacher recruitment process. Education does not change unless the way in which teachers are educated changes. 


\section{Professional Knowledge and Professionalism Teaching-Priority of Recognition in Nursing Teaching}

The ancestral way of practicing nursing activities privileged a handmade know-how transmitted between generations. Traditionally, their practices consisted in voluntaristic approaches and proactive assistance to the underprivileged, according to a control and direct dependence of religious orders and physicians. Several factors were being called to perspective this professional activity leading the search for new practices and own knowledge towards professional autonomy.

Considering profession's requirements evolution, training required was being restructured (Amendoeira, 2004; 2006; Graça \& Henriques, 2000; Nunes, 2003; Soares, 1993; 2011), going to be subjected to scientific scrutiny. At the national level, and since the 1980s, there was established a mandatory level of higher education, resulting in an increased demand of teachers to get their diplomas and/or validate the knowledge acquired in practice.

Unlike training planned in order to become a teacher in other levels of education, requiring pedagogical training for teachers in higher education in general and for the nursing teachers in particular, training is not planned, the dominant perspective continuing to be "Who knows how to do knows how to teach" (Masetto, 1998). On the other hand, at a social level, the territory of teachers' work had a self-demarcation, of an almost universal acceptance, whereby the teachers, originally the architects or masters of a particular craft, were the holders of knowledge that they passed on to their apprentices, propagating their art for future generations. For decades, the logic of transmission of knowledge and accumulated skills regulated the standard of teachers' performance in nursing.

Currently, the professional practice of teaching is not only to transmit knowledge, but also to create conditions for its own production and (re)construction. In higher education, teaching faces new territorialities, challenges, and realities, requiring new roles and responsibilities of teachers, another way of thinking and practicing teaching; teaching is under the aegis of "to make learn" (Roldão, 2007), looking ahead to the teacher as a facilitator and manager of learning.

All this is expected by teachers, but what do teachers expect in their work? Questions, such as what it means to be a teacher; what the meaning of the function of teaching is; what teachers are able to do; what professional knowledge supports teaching; and what the place of pedagogical training in teacher education is; are reflections that have come to thicken the agenda of many researchers. However, we are far from exhausting the field of worked knowledge that mobilizes teaching action, especially in nursing education, where demand for these answers is still insufficient.

In literature, several factors have been identified as influencing students' learning. Of the afore-mentioned factors, teacher quality is the most important one (Darling-Hammond, 1990), which emphasizes the relevance of training provided to who are going to teach.

\section{Methodology}

In understanding of professionalism teaching in nursing, it is intended here to study teachers' thinking in nursing through its representations and conceptions about teaching and the professional knowledge that supports it.

This research is founded on the professionalism teaching, while idealized set of knowledge, abilities, 
attitudes, norms, and skills is socially determined and necessary for the proper professional practice of teachers.

\section{Objective}

The objective of the study was to answer three questions: 1 . What perspectives of teaching do nursing teachers share? 2. What professional knowledge do nursing teachers recognize in the teaching practice? and 3. What training do nursing teachers indicate as a reference in terms of professionalism teaching?

\section{Research Design}

The study is part of the interpretative paradigm of educational research (Denzin \& Lincoln, 2000; 2008; Erickson, 1989; Lessard-Hébert, Gollete, \& Boutin, 2008; Tuckman, 2002) using the questionnaire. The construction of the questionnaire aimed to carry out semi-structured interviews to eight teachers. After validation of the pre-test in four nursing schools, the questionnaire was applied in 10 public nursing schools, where in a universe of 450 teachers, we obtained 227 valid responses. These numbers represent an overall response rate of about $50 \%$ of the questionnaires delivered. The size of the final sample obtained corresponds to a percentage of approximately $35 \%$ of the universe of teachers in Portuguese public nursing schools in higher education, value that seems to reflect a representative sample of their universe (M. Hill \& A. Hill, 2009).

\section{Ethical Considerations}

Given the principle of informed consent, the teachers were informed about the importance of their participation in the study and the research process and methodology defined, ensuring their anonymity and data confidentiality. Pondering possible implications of the disclosure of certain elements of the study, the anonymity of the nursing schools involved was ensured.

\section{Results}

\section{Interviews}

In the speech of the interviewees, the image of a professional with an identity process sustained on being a teacher seems to be prevailing, despite the manifestation of an identity representation of being a nurse, which calls for a composite identity (Mestrinho, 2012). In the interaction with various contexts, nursing teachers recognize themselves as a professional group anchored in nursing, but that, throughout the practice in teaching, nursing teachers make the transition into the teaching profession seeking a belonging to various social circles, common reality in the context of professional socialization.

Teaching seems to be interpreted by nursing teachers with the mission of "to make learn", operationalized by the meaning of conceptual transformation of students and skill development. To this end, nursing teachers are facilitators and managers of student learning, who being understood as active subjects and builders of their training. The interviewees viewed that a teacher should encourage bi-directional teacher-student relationships and select teaching strategies appropriate to a self-regulated learning.

Regarding the existing traits of a traditional teacher, inherited from the history of education itself and the professional practice of nursing, teachers seem to manifest an intention to counter ways of working that do not satisfy them (transmissive) as opposed to others they want (constructivist).

The requirement of teaching activity seems to involve a body of own knowledge and teaching professional skills in a dependent relationship among content knowledge, pedagogical knowledge, and content pedagogical knowledge (Shulman, 1986).

Among the professional skills relevant to teaching, collegiality (Zabalza, 2004) or the competence to 
promote the formation of learning communities with colleagues and other staff involved in teaching (Pérez, 2010) were proved to be a principle inherent to nursing teachers' education.

Within the scope of content knowledge, the vectors that seem to appear for the acquisition and development of teaching professional knowledge are conducting doctoral training and combined exercise of teaching with that of clinical nursing and clinical practice research in collaboration with the practitioners (work contexts nurses). In turn, within the scope of pedagogical knowledge, the emerging vectors are formal pedagogical training, institutionalization of pedagogical training, and research and reflection of teaching practice.

Referring teaching and research as two separate worlds, the interviewees claimed the indispensability of the teacher-conducted research in coordination with teaching, individually or in teams.

\section{Questionnaire}

The respondents indicated nursing teaching as a process of conceptual transformation of students and skill development, proposing to teachers the development of new challenges and consolidating the practice of new roles.

The teaching way of work that seems to be implicit in teachers' opinion reveals that teachers worried about "to make learn" and the students' learning process, developing teaching strategies that promote a reflective and critical attitude and facilitating a relationship of knowledge construction and not one of knowledge application are needed.

In the teaching practice, these nursing teachers seem to value the content pedagogical knowledge and the content knowledge (Shulman, 1986). Also, they value the ethical competencies and the ability to design the methodology, to organize learning activities, and to communicate and relate constructively (Perrenoud, 2008; Zabalza, 2004). These evidences suggest teachers with resources for action.

By comparing the dimensions of teaching professional knowledge and skills valued with the ones recognized as lacunars, it appears that both the content pedagogical knowledge and the content knowledge are considered important for the teaching practice, but at the same time, are considered in deficit. Similarly, the ability to design the methodology and organize learning activities was highlighted as very important in the teaching practice, and at the same time, is recognized as lacunar by teachers. The results indicate the need for teachers to invest at the pedagogical level and at the level of the discipline to teach.

The construction of epistemology of professional knowledge depends on several places, times, and temporal processes. For the respondents, this construction seems to depend on reflection about teaching practice, research in education, and research in nursing and professional experience, emphasizing that both the reflections, as the research of teaching practice, are self-recognized as lacunars. Indeed, the knowledge that these practices allow, as the role of the teacher enabler of research (Harden \& Crosby, 2000), could be concealed in nursing teaching, which reinforces the need for analytical-reflective teaching practices and research practices.

\section{Discussion}

Teaching seems to be envisaged as a process of conceptual transformation of students and skill development, undervaluing the significance of teaching as the education of "technical nurses". With dominant teachers' representation centered on individualization and autonomy of students' learning, the answers to the questionnaire show that nursing teachers enormously value the legal and institutional frameworks of education. 
These interpretations suggest a teaching thought in motion, oscillating between a transmissive teaching paradigm (Benner, Sutphen, Leonard, \& Day, 2010; Marques, 2002; Mestrinho, 2011).

The challenge of "to make learn" proposed to the teachers allows them to form reflective practitioners. Thus, great importance is attributed to active and participatory methodologies, from which, the teacher encourages investigative process in the students, with a view to its production of knowledge.

The intention to form reflective practitioners transfers for nursing teachers the need for a corresponding practice - reflective practitioner teachers - embodied in the knowledge and professional skills of professional teachers of education. As a complex activity, teachers show the need to master specific knowledge and professional skills suitable for the teaching practice, different from those acquired in clinical practice of nursing.

Thus, the content knowledge and the content pedagogical knowledge seem to define the types of professional knowledge that are most valued in this study, which are also recognized as lacunars. By not recognizing himself/herself as an expert in the content, the master-instructed teacher (Paquay, Parmentier, \& Van Nieuwenhove, 2009) does not seem a predominant thinking at nursing teachers, a different result from other studies (Benner et al., 2010; Marques, 2002; Mestrinho, 2012). The knowledge of the updated content is desired by the participants as a link to other knowledge considered, as an autonomous knowledge that a teacher himself/herself produces. In this commitment, the development of interventions in partnership with those involved in nursing education, targeting the educational experience as a place of the production of teaching professional knowledge and a field of teaching research, is a desired condition in the study. This condition seems to be a sign of professional autonomy, an autonomy with a great power for making decisions in a professional field historically marked by a prescriptive practice and knowledge consumption.

The skills conferred by the participants are in the pedagogical domain. The valued skills are recognized as lacunars in the teaching practice, which allows to infer pedagogical training needs in this group of teachers. Pedagogical training, particularly at the level of postgraduate studies, seems to be an area for the construction of teaching professional knowledge, enabling the teachers to have a new understanding (Shulman, 2004) of teaching and pedagogical action. To be perceived as a factor of professional development, pedagogical training becomes predominant in nursing education.

Doctoral education is also viewed as a space of production and development of disciplinary knowledge and professional skills, which gives teachers academic recognition.

Other sources of professional knowledge highlighted by the teachers were reflection, research, and professional experience from teaching practice and clinical practice in nursing. Reflection and research were proved to be decisive factors of professional development for learning, for the construction of teaching in nursing, for the development of clinical practice, as well as for the development of nursing disciplines (Amendoeira, 2004; Meleis, 2007). However, they were recognized as deficient in the teaching activity, confirming Vieira's statement that (2005) teaching research does not translate into an established practice in higher education teachers, being far from knowing, through teachers' voice, the role of professional knowledge and pedagogical training in the transformation of education practices, since its effects only come to us by those who speak and write about teachers and on teachers' behalf, but not by teachers themselves. Schön (1983) argued that it is necessary to put back teachers' work at the center of the research, as they are relevant stakeholders, subjects of knowledge, and specific knowledge holders. For this purpose, it is necessary to recognize that both teaching and research require a specific teacher training (Gibbs, 1995; Hattie \& Marsh, 1996; 
Nóvoa, 2012; Zabalza, 2006).

In the interviews, socialization and basic training in nursing were conceptualized as sources of professional knowledge, not being recognized as favored by the respondents.

Also, it is important to analyze the lowest relevance that seems to attribute to the scientific training of nursing for the teaching practice in the study. This outcome of the research seems to show a paradox in the teaching activity, since the access and teaching career promotion in nursing are dependent on training in the subject area. So, what seems to happen in this group of teachers is a lower valuation of this training to their practice teaching.

The respondents emphasize the expectation of a combined exercise between teaching and clinical practice, declaring clinical practice as a space of knowledge production of teachers, objectively, knowledge of the updated content. Nursing teachers' knowledge takes the characteristics that not only relate to the conceptual logic, but also to the instrumental and the nursing practice, which legitimates that they anchor their own construction on teaching experience and clinical experience as literature underscores (Amendoeira, 2004; 2006; Benner et al., 2010; Davis, Stullenbarger, Dearman, \& Kelley, 2005). However, among the respondents, teachers' performance as a model in nursing clinical practice does not seem to be absolutely relevant to teaching practice, which suggests an ambiguity in teachers' thinking, as stated in Amendoeira's works (2006; 2009).

The respondents emphasize a willingness to break with historical and structural forces that constrain and encrust both their thinking, and therefore, their action. Around a teacher professional culture, these teachers idealize certain aspects as contributory and drivers, in particular, the commitment and the teaching responsibility to education and to its practice in a collaborative and cooperative way. Collegiality is here defended by improving teaching and educational relationships, facilitating the learning of all stakeholders, and becoming a model of action for future professionals. With a practice of team work, the teachers develop more easily training strategies and devices funded in a pedagogical model where the students are assumed as active subjects who self-regulate their learning. About teacher development, Ponte (2004) underlined the value of collaboration as a powerful strategy to cope with complex problems, including many problems of professional practice, and stressed the value of a professional culture framed by a continuously reflective and transformative activity.

Indeed, based on the (im)possibilities perceived in the study, it seem to emerge paths of action based on an integrated view of the relationship between teaching and teaching professional knowledge. The appropriation of the professional knowledge base aims at an active teaching involvement in the construction of that knowledge, which involves the teachers' abilities to learn and processes of teaching professional development. In this study, It seems to be evident a willingness to learn and learn supposes rebuild in nursing teachers, restructure in a conscious and systematic way that various meanings and representations are built lifelong. Learning also implies knowing how to promote and rethink the knowledge arising from life experience and expanding the horizon of new experiences and new knowledge (Contreras, 2010). But for that to happen, structural, political, and institutional conditions are needed in nursing education.

Given the expressions of interests, desires, and expectations of change, perceived difficulties and shortcomings and lack of training for the teaching practice revealed, it is noted in this group of teachers the power to promote their own professional development (Pérez, 2010).

In short, we circumscribe the professionalism teaching in nursing in the dialectical relationship between 
theoretical knowledge and the knowledge resulting from practice and professional experience, highlighting the importance of research and the perceived need for pedagogical training in teaching professional education, as shown by the reflection produced nationally about the need for pedagogical training in higher education (Nóvoa, 2012; Reimão, 2001; Rosado, 2008; Vieira, 2005). Considering the thinking of the teachers from this study, it seems desirable that nursing teaching does not constitute a mere application of the knowledge that is learned informally, but also of the knowledge worked from the conceptual point of view (Nóvoa, 2002); an ability to act before the unpredictability of teaching situations (Le Boterf, 1997; Lessard, 2009).

\section{Conclusions}

This study has three major conclusions: 1 . The mission of nursing education is to make learn; 2 . The knowledge of the professional teachers of education is embedded in nursing education; and 3 . The pedagogical training in the processes of (trans)formation and teachers' professional development in nursing.

\section{The Mission of Nursing Education Is to Make Learn}

The reforms produced in nursing at higher education level have been several, of several orders and dependent on various factors responsible for a new professionalism teaching.

Nursing teaching seems to be thought in an articulated way with its political and social contexts, and it is considered as a complex and dynamic activity that happens in the constellation of relationships and interactions with others and itself, suggesting an extended professionalism teaching (Hoyle, 1980). The teaching profile seen in this study reflects that the teachers are capable of adhering to the management of an institutional and curricular project and are able to face and solve problems in teaching, to reflect before, during, and after its action (Schön, 1983).

The idealized image of teaching activity is a positive image and the result of the process of collective construction of teachers, which integrates a product of individual construction. Sometimes, the construction that sometimes seems to be perceived as solidary and sometimes as lonely. This idea reinforces an identity process based predominantly on being a teacher and that refers to a (re)construction of his/her professional training.

The role transition of teachers from the transmitters of knowledge to the facilitators and managers of student learning renews the meaning of nursing teaching, define a student's conceptual transformation and skill development. Teacher-centered in the students and in his/her learning (Feixas, 2002) reveals a dominant teacher profile, indicating advances in scientific knowledge on this topic in relation to other studies in Portugal (Amendoeira, 2009; Benner et al., 2010; Marques, 2002; Mestrinho, 2011). A teacher is seen as an actor who cares about education, who promotes a self-regulated learning through active and participatory pedagogical activities, who has a close relationship with the students, who manages social spaces, inside and outside the education institution, and who is divided between the unfavourable feeling of individualism and the expectation of collegiality. Indeed, while representations and beliefs about the nature of teaching work, critical paradigm of teaching seems to unfold (Paquay et al., 2009), defining teaching as a set of attitudes, investigative, critical, and reflection processes, where teachers build a systematic experiential knowledge, which can be communicated, reflecting one's practices and producing innovative teaching tools.

Thus, the identification of performance is associated with own responsibilities, consistent with a transformed and transformative teaching, and related to the moral commitment implicit in the action of a teacher and with his/her own, to form reflective practitioners and configure nursing education with the mission to make learn. 


\section{The Knowledge of the Professional Teachers of Education Is Embedded in Nursing Education}

Faced with the question of their frames of references and a focus on their professional (lack of) knowledge, the teachers expressed that a paradoxical professional knowledge situated between knowing what to do and accepting not knowing it (Contreras, 2010).

Aiming to its nature, teachers appreciated for the exercise of teaching content knowledge and content pedagogical knowledge (Shulman, 1986), a situation that points new ways to professionalism teaching. Similarly, these two types of knowledge have been recognized as lacunars in nursing teaching.

According to the dimensions of knowledge and professional skills revealed, nursing teaching seems to be viewed on the margin of a traditional teaching practice - technical teachers of education — supported in an instrumental know-how and in the application of a consumed knowledge. Bringing new contributions to research, nursing teaching seems to be conceptualized through the practice of reflective practical teachers (Zeichner, 1983).

The moments of debate and reflection, individually and collectively, on teaching practice and clinical practice, leading to interventions and projects in partnership, are recognized as idealized spaces of knowledge construction that should be mobilized in teaching practice. Knowing how to justify the practice through reflection on itself leads a teacher to the status of an expert teacher.

Teaching seems to be determined by a teacher's willingness to learn and to produce own knowledge, particularly through research. Still, the distance between teaching function and research function seems to be worrying, devising their articulation, because researching one's own practice is a powerful way of learning. This finding enables us to sustain the important role of scholarship of teaching (Shulman, 2004) in nursing education, giving a way to teaching based on evidence, corroborated by the perspectives on privileged sources of teaching professional knowledge: reflection on teaching practice, research, teaching and clinical practice, and professional experience. Thus, the professional knowledge that seems to be embedded in nursing education suggests an approximation to the profile of a professional teacher of education.

\section{The Pedagogical Training in Processes of (Trans)Formation and Teachers' Professional Development in Nursing}

At various stages of the research, nursing teachers highlighted the need for greater educational investment, such as a pedagogical training focused on teaching practice, cooperative work, and educational innovation projects. The search for these spaces will hold, possibly with its perception that teaching requires more than disciplinary knowledge, highlighting the need for theoretical frameworks that enable to support their work, particularly within the context of learning theories, pedagogical relationship, planning, implementation of teaching, pedagogical methodologies, and assessment. This representation seems to meet the idea that the knowledge of teacher education should be transformative, making the training into an experience, which can be understood as a teaching opportunity to other forms of knowledge and other forms of relationship with knowledge, as a teaching opportunity to a thinking about yourself and other forms of relationship with yourself, and as a source of knowledge and of being a teacher (Contreras, 2010). Nursing teachers' professional development must be practice-oriented in order to be effective and to have an impact on nursing teachers' professional practice.

Nursing schools are also called to take their responsibilities in their teacher training, encouraging teachers' projects and collaborative research aimed at solving problems. Indeed, the evidence allows to emphasize the importance of education institutions to have a cabinet of pedagogical training, designing teacher training as a 
relevant process of metamorphosis and an internal process of reorientation and transformation that recovers and relies on previous acquisitions and precedes a lasting and sustainable external transformation in education. Teacher education is certainly one of the most crucial challenges facing education reform. Thus, this study underlines nursing teachers' practice with new professionalism teaching.

\section{Limitations of This Study}

The small amount of research on professional knowledge and professionalism teaching in the field of nursing education was a limitation of the study, in the sustainability of opinions of other investigators.

Like internal human phenomena, not observable and hardly perceived by the investigator, we witnessed that the domain of teaching conceptions in nursing is a very fertile field of research, still, little has been explored, but with openness to inquiry.

The interviews gave a greater contribution to the investigation than that originally been planned. Because of that and the complex exploration that they allowed to the field of nursing teaching, we consider the number of the respondents to be another limitation of the study.

The choice of the questionnaire as a benchmark of professionalism teaching may be have been an ambitious choice for teachers' conceptions in relation to teaching and professional knowledge, covering a wide range of possibilities, so that can be projected on an instrument of this nature.

Finally, we share that the condition of belonging to the professional field study contributed, at times, for a tendency of identification with the experiences of the participants. Imposing the proper critical distance, the search for meaning to our investigative concerns, the limits of our knowledge, and the requests for a "think again", led us to the experiential knowledge (Contreras, 2010).

\section{References}

Amendoeira, J. (2004). Enfermagem em Portugal: Contextos, actores e saberes (Nursing in Portugal: Contexts, actors and knowledge). Enfermagem, 35(36), 13-22.

Amendoeira, J. (2006). Uma biografia partilhada da enfermagem (A shared biography of nursing). Coimbra, P.T.: Formasau.

Amendoeira, J. (2009). Ensino de enfermagem: Perspectivas de desenvolvimento (Nursing teaching: Development perspectives). Pensar Enfermagem, 13(1), 2-12. Retrieved from http://pensarenfermagem.esel.pt/files/2009_13_1_2-12(2).pdf

Benner, P., Sutphen, M., Leonard, V., \& Day, L. (2010). Book highlights from educating nurses: A call for radical transformation. San Francisco, C.A.: Jossey-Bass.

Contreras, J. D. (2010). Ser y saber en la formación didáctica del profesorado: Una visión personal (Being and knowing in teaching teacher education: A personal view). Retrieved from http:/www.redalyc.org/src/inicio/ArtPdfRed.jsp?iCve=27419198004

Cunha, M. I. (Org.). (2005). Formatos avaliativos e concepção de docência (Assessment formats and design teaching). Campinas, São Paulo: Autores Associados.

Cunha, M. I. (Org.) (2007). Reflexões e práticas em pedagogia universitária (Reflections and practices in university pedagogy). Campinas, São Paulo: Papirus.

Darling-Hammond, L. (1990). Teachers and teaching: Signs of a changing profession. In W. R. Houston (Org.), Handbook of research on teacher education (pp. 267-290). New York, N.Y.: McMillan.

Davis, D., Stullenbarger, E., Dearman, C., \& Kelley, J. A. (2005). Proposed nurse educator competencies: Development and validation of a model. Nursing Outlook, 53, 206-211.

Denzin, N., \& Lincoln, Y. (Ed.). (2000). Handbook of qualitative research (2nd ed.). London, U.K.: Sage Publications, Inc..

Denzin, N., \& Lincoln, Y. (2008). The landscape of qualitative research (3rd ed.). Thousand Oaks, C.A.: Sage Publications, Inc..

Erickson, F. (1989). Métodos cualitativos de investigación sobre la enseñanza (Qualitative methods of research on teaching). In M. C. Wittrock (Ed.), La investigación en la enseñanza II. Métodos cualitativos de observación (Research in teaching II. Qualitativemethods of observation) (pp.195-301). Madrid, E.S.: Ediciones Paidós Ibérica, S.A. 
Estrela, M. T. (2001). Questões de profissionalidade e profissionalismo docente (Issues of professionalism and teaching professionalism). In M. Teixeira (Org.), Ser professor no limiar do século XXI (Being a teacher at the threshold of the 21st century) (pp. 113-142). Porto, P.T.: Edições ISET.

Estrela, M. T. (2005). Os saberes dos docentes vistos por eles próprios (The knowledge of teachers viewed by themselves). Revista Portuguesa de Pedagogia, 39(2), 444-450.

Feixas, M. C. (2002). El desenvolupament professional del professor universitari com a docente (Professional development of teacher university) (Doctoral dissertation, University of Barcelona).

Fenstermacher, G. (1986). Philosophy of research on teaching: Three aspects. In M. C. Wittrock (Ed.), Handbook of research on teaching (3th ed.) (pp. 37-49). New York, N.Y.: Macmillan.

Gibbs, G. (1995). The relationship between quality in research and quality in teaching. Quality Higher Education, 1(2), $147-157$.

Graça, L., \& Henriques, I. (2000). Evolução da prática e do ensino da enfermagem em Portugal (Evolution of practice and nursing education in Portugal). Retrieved from http://www.ensp.unl.pt/luis.graca/textos62.htm

Harden, R. M., \& Crosby, J. R. (2000). The good teacher is more than a lecturer-The twelve roles of the teacher. London, U.K.: AMEE.

Hattie, J., \& Marsh, H. W. (1996). The relationship between research and teaching: A meta-analysis. Review of Educational Research, 66(4), 507-542.

Hill, M. M., \& Hill, A. (2009). Investigação por questionário (Research questionnaire) (2th ed.). Lisbon, P.T.: Edições Sílabo.

Hoyle, E. (1980). Professionalization and desprofessionalization in education. In E. Hoyle, \& J. Magerry (Orgs.), World yearbook of education 1980: Professional development of teachers (pp. 42-54). London, U.K.: Kogan Page.

Le Boterf, G. (1997). De la compétence à la navigation profissionnelle (The jurisdiction of vocational navigation). Paris, F. R.: Les Éditions D’Organisation.

Lessard, C. (2009). O trabalho docente, a análise da actividade e o papel dos sujeitos (Teaching work, analysis of the activity and the role of subject). Retrieved from http://sisifo.fpce.ul.pt

Lessard-Hébert, M., Gollete, G., \& Boutin, G. (2008). Investigação qualitativa: Fundamentos e práticas (Qualitative research: Principles and practices) (4th ed.). Lisbon, P.T.: Instituto Piaget.

Marques, M. F. M. (2002). Entre a continuidade e a inovação: O ensino superior de Enfermagem e as práticas pedagógicas dos professores de Enfermagem (Between continuity and innovation: The nursing education and the pedagogical practices of teachers of nursing) (Master's thesis, Lusophone University of Humanities and Technologies).

Masetto, M. (1998). Docência na universidade (Teaching in university) (5th ed.). Campinas, São Paulo: Papirus.

Meleis, A. I. (2007). Theoretical nursing: Development and progress (4th ed). Philadelphia, P.A.: Lippincott.

Mestrinho, M. G. (2011). Profissionalismo e competências dos professores de enfermagem (Professionalism and skills of nursing teachers) (Doctoral dissertation, Institute of Education, University of Lisbon).

Mestrinho, M. G. (2012). Ensino de enfermagem: Caminhos de mudanza na formação de profesores (Nursing teaching: Paths of change in teachers training). Loures, P.T.: Lusociência.

Montero, L. (2005). A construção do conhecimento profissional docente (The construction of teachers' professional knowledge). Lisboa, P.T.: Instituto Piaget.

Nóvoa, A. (2002). Formação de professores e trabalho pedagógico (Teacher training and pedagogical work). Lisbon, P.T.: Educa.

Nóvoa, A. (2012). Pedagogia universitária: Já estamos no séc. XXI ou ainda não? (University pedagogy: We are already in the century XXI or not?). Paper presented at The VII Iberoamerican Congress of University Teaching. Higher Education-Innovation and Quality in Teaching, Porto, Portugal.

Nunes, L. (2003). Um olhar sobre o ombro: Enfermagem em Portugal (1881-1998) (A glimpse of the shoulder: Nursing in Portugal (1881-1998)). Loures, P.T.: Lusociência.

Paquay, L., Parmentier, P., \& Van Nieuwenhove, C. (2009). When the university supports teacher training in higher education? Bruxelles, B.E.: De Boeck.

Pérez, G. A. (2010). Nuevas exigencias y escenarios para la profesión docente en la era de la información y de la incertidumbre (New demands and scenarios for the teaching profession in the era of information and uncertainty). Retrieved from http://www.redalyc.org/src/inicio/ArtPdfRed.jsp?iCve=27419198002

Perrenoud, P. (2000). Dez novas competências para ensinar (Ten new skills to teach). Porto Alegre, B.R.: Artes Médicas-Sul.

Perrenoud, P. (2001). Porquê construir competencias a partir da escola?(Why build skills from school?). Porto, P.T.: ASA Editores. 
Perrenoud, P. (2008). Transmisión de conocimientos y competencias (Transmission of knowledge and skills). Retrieved from $\mathrm{http}: / /$ www.octaedro.com/ice/pdf/5CUADERNO.pdf

Ponte, J. P. (2004). Os cursos de formação de professores à luz do processo de Bolonha (Training courses for teachers in the light of the Bologna process). Retrieved from http://www.educ.fc.ul.pt/docentes/jponte/artigos-por-temas.htm

Reimão, C. (Org.) (2001). A formação pedagógica dos professores do ensino superior (The pedagogical training of university teachers). Lisbon, P.T.: Edições Colibri.

Roldão, M. C. (2005). Profissionalidade docente em análise-Especificidades dos ensinos superior e não superior (Teaching profession-Specific analysis at the higher levels and not more). Revista NUANCES, 14(13), 108-126.

Roldão, M. C. (2007). Função docente: Natureza e construção do conhecimento profissional (Teaching function: Nature and the construction of professional knowledge). Revista Brasileira de Educação, 12(34), 94-103. Retrieved from http://www.scielo. br/pdf/rbedu/v12n34/a08v1234.pdf

Rosado, P. P. (2008). Formação pedagógica no ensino superior: O caso dos docentes médicos (Teacher training in higher education: The case of the medical faculty). Sísifo. Revista de Ciências da Educação, 7, 111-124. Retrieved from http://sisifo. fpce.ul.pt

Schön, D. A. (1983). The reflective practitioner: How professionals think in action. New York, N.Y.: Basic Books.

Schön, D. A. (1987). Educating the reflective practicioner. São Francisco, C.A.: Jossey-Bass.

Shavelson, R. J. (1992). New roles for teachers and students. In: F. K. Oser, A. Dick, \& J. Patry (Eds.), Effective and responsible teaching: The new synthesis (pp. 80-90). San Francisco, C.A.: Jossey-Bass.

Shulman, L. (1986). Those who understand: Knowledge growth in teaching. Educational Researcher, 15(2), 4-18.

Shulman, L., \& Shulman, J. (2004). How and what teachers learn: A shifting perspective. Journal of Curriculum Studies, 36(2), 257-271.

Soares, M. I. (1993). Da touca de brim à blusa branca: Contributo para a história do ensino da Enfermagem em Portugal (1880-1950) (The cap to the brim white blouse: Contribution to the history of nursing education in Portugal (1880-1950)). Lisbon, P.T.: Portuguese Association of Nurses.

Soares, M. I. (2011). Nursing education in Portugal, last 50 years revolution. 19th Florence Network, Lisbon, Portugal.

Tuckman, B. (2002). Manual de investigação em educação (Handbook of research in education). Lisbon, P.T.: Fundação Calouste Gulbenkian.

Vieira, F. (2005). Transformar a pedagogia na universidade? (Transforming pedagogy at the university?). Currículo sem Fronteiras, 5(1), 10-27. Retrieved from http://www.curriculosemfronteiras.org/vol5iss1articles/flavia1.pdf

Vieira, F. (2011). A experiência educativa como espaço de (trans)formação profissional (The educational experience as space of (trans) formation). LINGVARVMARENA, 2, 9-25.

Zabalza, M. A. (2003). Las competências docentes del professorado universitário (The teachers' skills in university). Madrid, E.S.: Narcea.

Zabalza, M. A. (2004). O ensino universitário: Seu cenário e protagonistas (University education: Its scenery and actors). Porto Alegre, B.R.: Artmed Editora.

Zabalza, M. A. (2006). La convergencia como oportunidad para mejorar la docência universitaria (The convergence as an opportunity to improve university teaching). Revista Interuniversitaria de Formación del Profesorado, 20(3), 37-69.

Zabalza, M. A. (2007). Competencias docentes del profesorado universitario: Calidad y desarrollo profesional (Teaching skills of university teachers: Quality and professional development). Madrid, E.S.: Narcea.

Zabalza, M. A. (2009). Ser profesor universitário hoy (To be university teachers today). La Cuestión Universitária, 5, 69-81. Retrieved from http://www.lacuestionuniversitaria.upm.es/web/boletin.php

Zeichner, K. M. (1983). Alternative partadigms of teacher education. Journal of Teacher Education, 34(3), 3-9. 